\title{
Working in gender-dominated occupations and depressive symptoms: findings from the two age cohorts of the lidA study
}

\author{
Silke Tophoven · Jean-Baptist du Prel • Richard Peter • \\ Veronika Kretschmer
}

Published online: 25 July 2014

(C) Institut für Arbeitsmarkt- und Berufsforschung 2014

\begin{abstract}
Gender-specific differences in the frequency of depression to the disadvantage of women have been known for decades. In Germany, there is evidence that the prevalence of mental disorders also differs by occupation. The present study investigates whether for women working in male-dominated occupations and for men working in female-dominated occupations is related to depressive symptoms independently from other factors like work stress and work-family conflict. Special attention is paid to gender differences. Moreover, women are distinguished according to their working time (full-time or not). We use data from the first wave of the lidA study for our analyses. We make use of the applied Beck Depression Inventory, the effortreward imbalance scales as well as the work-family conflict scale. Occupational gender segregation is defined as a share of $80 \%$ of men and women per occupation, respectively. For women, the results of the multivariate analyses show an independent relationship between depressive symptoms and working in male-dominated occupations. Furthermore, significant interactions between occupational gender segregation and work stress are observed in both men and women regarding depressive symptoms.
\end{abstract}

\section{S. Tophoven $(\bowtie)$}

Institute for Employment Research (IAB),

Regensburger Straße 104, 90478 Nuremberg, Germany

e-mail: silke.tophoven@iab.de

\section{J.-B. du Prel · R. Peter}

Institute of the History, Philosophy and Ethics of Medicine,

Ulm University, Germany

V. Kretschmer

Bergische University of Wuppertal,

Germany
Keywords Gender · Occupational gender segregation · Depressive symptoms - Work stress - Work-family conflict

JEL classification $\mathrm{J} 16 \cdot \mathrm{J} 24 \cdot \mathrm{I} 14 \cdot \mathrm{J} 28$

\section{Geschlechterdominierte Berufe und Depressivität: Ergebnisse zu den zwei Alterskohorten der lidA-Studie}

Zusammenfassung Seit Jahrzehnten sind geschlechtsspezifische Unterschiede im Auftreten von Depressionen zum Nachteil von Frauen bekannt. In Deutschland gibt es Hinweise darauf, dass sich die Prävalenz von psychischen Störungen auch in Abhängigkeit des Berufs unterscheidet. Die vorliegende Studie untersucht, ob die Tätigkeit in einem Männerberuf für Frauen oder in einem Frauenberuf für Männer mit Depressivität zusammenhängt unabhängig von weiteren Faktoren wie Arbeitsbelastungen und WorkFamily Konflikt. Ein besonderes Augenmerk wird dabei auf geschlechtsspezifische Unterschiede gelegt sowie für Frauen zudem auf Unterschiede nach dem Umfang der Erwerbstätigkeit. Für unsere Analysen verwenden wir die Daten der ersten Welle der lidA-Studie. Wir nutzen das vereinfachte Beck-Depressions-Inventar, Skalen zur Messung beruflicher Gratifikationskrisen sowie des Work-Family Konflikts. Ein Anteil eines Geschlechts von 80 Prozent pro Berufsangabe wird verwendet, um die Dominanz eines Geschlechts zu bestimmen. Die Ergebnisse multivariater Analysen zeigen, dass Frauen in männerdominierten Berufen signifikant höhere Depressivitätswerte aufweisen. Weiterhin können signifikante Interaktionen zwischen beruflicher Geschlechtersegregation und wahrgenommenen Arbeitsbelastungen für Frauen und Männer in Bezug auf Depressivität berichtet werden. 
Schlüsselwörter Geschlecht · Berufliche

Geschlechtersegregation - Arbeitsbelastung ·

Work-Family Konflikt · Depressivität

\section{Introduction}

Depression is the mental disease leading to the highest percentage of sickness absence of all mental diseases in Germany (Techniker Krankenkasse 2008). Working days lost due to mental disorders show the highest increase since 2000, while decreasing for all other diseases. In general, the prevalence of depressive symptoms is higher in women than in men (e.g., Kessler 2003; Nolen-Hoeksema 2001). Accordingly, the percentage of mental disorders, especially of depression and other affective disorders, of all reasons for sickness absence is also higher in women than in men (Meyer et al. 2012). Furthermore, mental disorders were the main reason for the transition to disability pension (men: 35.2\%; women: 47.4\%) in 2011 (Deutsche Rentenversicherung Bund 2012). The investigation of work-related causes for depressive symptoms is therefore of high medical as well as economic relevance (Jacobi et al. 2004; Rau et al. 2010; Techniker Krankenkasse 2008).

Nowadays, employees of both genders are increasingly faced with work-related factors for poor mental health, which can also be traced back to the gender-segregated labour market and typically male and female work tasks (Bildt and Michélsen 2002; Payne and Doyal 2010). In Germany, there is evidence that the prevalence of mental disorders differs strongly by occupation and occupational sector. Persons employed in the service sector and in emotionally involving occupations show a higher prevalence of sickness absence caused by mental disorders (Meyer et al. 2012). In particular in strongly gender-segregated occupations, both genders show a higher incidence rate of work-related hassles, job strain and sickness absence. Women in maledominated occupations tend to report more anxiety or mood disorders (Evans and Steptoe 2002; Hensing and Alexanderson 2004; Mota et al. 2012), while male employees in female-dominated occupations report more ill-health symptoms (Svedberg et al. 2009). Moreover, for women, Peter et al. (2006) detect a relationship between over-commitment and working in male-dominated occupations examining myocardial infarction risk. Thus, working as minority group in opposite-gender dominated settings seems to be a risk factor for poor health.

According to literature research, several work-related psychosocial factors are also related to mental health. For instance, perceived work stress functions as a strong predictor of depression among men and women (Munce et al. 2006). This association also became apparent when using one of the best established instruments to measure work- related stress: the effort-reward imbalance model (e.g., Godin et al. 2005; Schulz et al. 2011; Tsutsumi et al. 2012). Furthermore, inter-role conflicts emerging from both work and family demands can be reported to lead to negative work-related, non-work-related and stress-related consequences (Allen et al. 2000). Several studies have already shown a significant association between work-family conflict and depression (e.g., Kato and Yamazaki 2009; Wang et al. 2012). In this context, depression can also be determined as one stress-related health complaint (van Veldhoven and Beijer 2012).

Against this background, we aim to answer the question to what extent depressive symptoms are associated with employment in gender-dominated occupations with particular regard to women in male-dominated occupations in comparison to women in female-dominated occupations and to men in female-dominated occupations in comparison to men in male-dominated occupations. We examine these relationships separately for men and women. Additionally, we adjust the relationship between occupational gender segregation and depressive symptoms for perceived work stress and work-family conflict. To better understand possible associations between working in gender-dominated occupations and depressive symptoms, we also aim at investigating the role of interactions between gender domination and work stress as well as work-family conflict in association with depressive symptoms.

The paper is structured as follows: Section 2 provides a theoretical background as well as an overview on previous research related to our research questions and leads to concluding assumptions. In Sect. 3 we describe methods and data used. Our results are presented in Sect. 4. The last section concludes with a discussion of the results as well as strengths and limitations of our study and concluding remarks on our findings.

\section{Background}

\subsection{Occupational gender segregation}

The German labour market is highly gender-segregated in two directions, i.e. vertically and horizontally (Achatz 2008). Our investigation focuses on horizontal segregation which can be defined as a typical gender distribution over occupations, more precisely a certain dominant concentration of female and male workers (Achatz 2008; Blackburn et al. 2002; Charles 2003). Blackburn et al. (2002) describe changes in education, occupational structure and the increased female labour force participation as important preconditions as well as simultaneous processes to understand the concentration of men and women in different occupations. In addition, typical gender role behaviour and 
prevailing societal gender stereotypes lead to a classification into male and female occupations (Beck-Gernsheim 1979; Busch 2013). Thus, typically female occupations are known to involve principally non-manual tasks, such as service professions or child care, while typically male occupations are mainly characterised by manual tasks that are, for instance, physically demanding (Charles 2003). Furthermore, male professions often provide higher income, more stability and higher prestige besides increased physical demands, while female professions are associated with lower income and few career prospects and are said to have better possibilities to work fewer hours and reconcile work and family life in compensation (Busch 2013; Hultin 2003). In 2009 , nearly one in two men (49\%) and more than one in three women $(36 \%)$ worked in a profession with a gender ratio of 4:1 (Federal Statistical Office 2012). Accordingly, only small proportions of males and females work in occupations dominated by the opposite gender.

\subsection{Occupations dominated by the opposite gender and depressive symptoms}

In the field of occupational stress research, several studies revealed that psychological disorders, for instance depression, may be caused by work-related stressors or structural occupational factors (overview in Tennant 2001). According to previous research, employment in gender-dominated occupations might be associated with health differences or even mental disorders in comparison to employment in gender-integrated occupations with nearly the same gender proportion (Bryngelson et al. 2011). To explain possible health effects of such gender imbalances in the workplace, Kanter's theory of tokenism (1993) can be used. She argues that a minority status in the workplace may lead to unequal treatment by colleagues belonging to the majority. According to this theoretical concept, women working in male-dominated occupations (fire department, etc.) or men in female-dominated occupations (nursing, etc.) may be seen and treated as representatives of a minority group or also called tokens. Individuals are referred to as tokens if their social category, such as gender or race, is different from the majority of the work group in an organization or occupation, namely a minority group. In this respect, different group types are defined according to the numerical ratio of majority to minority organizational members. The so-called "skewed" group consists of the typical proportion of approximately 15 tokens and 85 majority individuals, whereas in a "balanced" group there is an almost equal number of individuals in the two groups. In the theory of Kanter (1993) the focus lies on female minorities or tokens and her findings are transferred to all minority groups. In an occupational setting, minorities are under special observation, faced with high expectations or stereotypes regarding their work performance and confronted with increased barriers, such as social isolation by the dominant group. Thus, it becomes evident that working in occupations dominated by the opposite gender may result in increased work stress, reduced psychological wellbeing and higher rates of work-related hassles and longterm sickness absence, while gender-integrated workplaces are mostly not associated with any negative mental health effects (Bryngelson et al. 2011).

Research findings further indicate that negative health effects of gender-dominated occupations also differ between males and females. In women, a higher incidence rate of anxiety or mood disorders can be determined in male-dominated occupations (Hensing and Alexanderson 2004; Mota et al. 2012). Generally, females perceive more job demands in professions dominated by the opposite gender than males (Hochwarter et al. 1995). Concerning male employees, more ill-health symptoms, such as sleeping disorders, are reported in female-dominated occupations than in other types of workplaces (Svedberg et al. 2009). However, in occupations that are particularly strongly dominated by the opposite gender, both women and men show a higher incidence rate of work-related hassles, job strain and sickness absence (Hensing and Alexanderson 2004).

\subsection{Further work-related factors and depressive symptoms}

\subsubsection{Work stress}

Aside from occupational gender segregation, genderspecific differences in depression rates among employees might also be explained by variations in working conditions and work-related stress. Previous research identified that the experience of work stress is related to depression in women and men (e.g., Dragano et al. 2008; Godin et al. 2005). In line with this, the Canadian Community Health Survey also showed that work stress functions as one strong predictor of depression among working individuals with a two times higher prevalence of depression in women than in men (Munce et al. 2006). Furthermore, it was discovered that women report higher levels of work-related stress than men do (Whitley et al. 1991). Godin et al. (2005) detected that cumulative work stress is strongly related to mental health among women. Work-related stress is often measured with the help of the effort-reward imbalance ratio (ERI ratio) (Siegrist 1996; Siegrist et al. 2004). This theoretical model assesses and facilitates the understanding of psychosocial work stress. The underlying concept is the assumed social reciprocity within work contracts: Employees exchange their job performance (efforts) for rewards (money, esteem and status control). The model distinguishes between an extrinsic (e.g., efforts, rewards as perceived by the working person) and an intrinsic component (e.g., individual dealing with demands and his or her reward expectations) of work 
stress. Both components per se are expected to be stressful and it is assumed that they become most distressing in combination. According to the model, distress is likely to occur in working situations where high efforts are spent and low rewards obtained (Siegrist et al. 2004). Findings reveal that an imbalance of efforts and rewards predicts poor selfreported health, reduced well-being and even physiological indices of ill-health (Bathman et al. 2013; de Jonge et al. 2000; Godin and Kittel 2004; Li et al. 2006; Pikhart et al. 2004; Siegrist et al. 2004). Moreover, a reciprocal influence between ERI and adverse health effects (i.e. psychological distress and physical complaints) was reported (Shimazu and de Jonge 2009).

To explain differences in health-related outcomes for other diseases, a different exhaustive work-related coping style between men and women was already determined to be one reason. It was shown that overcommitment was associated with adverse health outcomes (e.g., Chandola et al. 2008; Hintsanen et al. 2007; Lau 2008; Peter et al. 1998; Peter et al. 2006; Siegrist et al. 2004). According to the outlined research findings, we adjust the relation between gender segregation and depressive symptoms for work stress.

\subsubsection{Work-family conflict}

Nowadays, both female and male employees are increasingly faced with having to balance their work and family roles. Besides work demands, both genders have to deal with domestic obligations (Bond et al. 1998). This is due to the demographic trends of a growing number of dual-career couples, employed single parents and working mothers in the modern labour market (Galinsky et al. 2011). However, especially women are still more likely than men to have a double burden reconciling paid and unpaid work and family life (Cramm et al. 1998; Payne and Doyal 2010). If the role pressures from both work and family domains are mutually incompatible, an inter-role conflict can emerge (Greenhaus and Beutell 1985). Literature reports two directions of the work-family imbalance. In terms of the work-family conflict, the work role may interfere with the family role and conversely, regarding the family-work conflict, the family role may disturb the work role (Frone 2003). Regarding the work-family conflict, a significantly higher prevalence rate can be assumed in comparison to the family-work conflict (Eagle et al. 1997; Frone et al. 1992). Furthermore, several meta-analyses investigated the work-family conflict and attempted to establish an explanatory model of the outcomes (Allen et al. 2000; Amstad et al. 2011). One framework of Allen et al. (2000) describes that the work-family conflict may result, inter alia, in negative work-related, non-work-related and stress-related consequences like depression (Major et al. 2002; van Veldhoven and Beijer 2012). Furthermore, gender differences concerning work- family conflict were reported. According to recent research, employed women generally perceive higher work-family conflict than their male colleagues (Grandey and Cropanzano 1999; Haines et al. 2008; van Veldhoven and Beijer 2012). Furthermore, several research results find a positive direct relationship of work-family conflict and depression (Frone et al. 1996; Kirchmeyer and Cohen 1999). Additionally, recent research assumes that workplace stressors are clearly related to work-family conflict (Byron 2005). Consequently, our study also includes work-family conflict to adjust the relation between gender segregation and depressive symptoms.

\subsection{Summarising assumptions}

In our study, we aim to answer the question to what extent depressive symptoms are associated with employment in gender-dominated occupations with particular regard to women in male-dominated occupations in comparison to women in female-dominated occupations and to men in female-dominated occupations in comparison to men in male-dominated occupations. According to the described findings on occupational gender segregation and mental health in this section, and following the theory of Kanter (1993), we expect a higher risk of depressive symptoms for women and men working in occupations dominated by the opposite gender. Additionally, as described above, gender differences in psychosocial exposure at the worksite and perceived work-family conflict might contribute to the explanation of depressive symptoms. Therefore, we adjust the relationship between occupational gender segregation and depressive symptoms for work stress and work-family conflict. In order to shed more light on possible associations between working in gender-dominated occupations and depressive symptoms, we also investigate the role of interactions between working in occupations dominated by the opposite gender and work stress as well as work-family conflict in association with depressive symptoms.

\section{Data and methods}

\subsection{Database}

For our analyses, we use data from the first wave of the lidA study (leben in der Arbeit - German Cohort Study on Work, Age and Health) with 6585 male and female participants born either in 1959 or 1965 who were subject to social insurance contributions on December 31, 2009. ${ }^{1}$ The sample was randomly drawn from administrative data of the Fed-

\footnotetext{
${ }^{1}$ Self-employed persons, freelancers and officials are not subject to social insurance contributions in Germany.
} 
eral Employment Agency (Hasselhorn et al. 2014; Schröder et al. 2013). In our study, we concentrate on men and women who were employed at the interview date. Therefore, our study population comprises persons who were working part-time or full-time or in marginal employment and who were not self-employed or working as civil servants at the interview date $(n=6110)$.

The data were collected using computer-assisted personal interviews in 2011. However, with one exception, the applied version of the Beck Depression Inventory (BDI-V) (Beck et al. 1988; Schmitt et al. 2006) was inquired with a paper-pencil questionnaire during the personal interview to reduce social desirability and interviewer effects. Since not every respondent returned the paper-pencil questionnaire during the interview or sent it back to the survey institute, some questionnaires are missing. Regarding incomplete questionnaires, the data of 641 persons is missing for depressive symptoms. Another high number of missing values can be detected for the effort-reward imbalance ratio which consists of 17 items (153 missing values). Finally, our study population comprises 5221 working males and females born in 1959 or 1965 (cf. Table 1).

\subsection{Measures}

\subsubsection{Depressive symptoms}

The level of depressive symptoms is measured using the 20-item applied Beck Depression Inventory, BDI-V (Beck et al. 1988; Schmitt et al. 2006). The BDI-V covers 20 symptoms on a six-point rating scale ranging from 0 'never' to 5 'almost always'.

With at least 18 valid answers given ${ }^{2}$, the answers were summed up to a score ranging from 0 to 89 (cf. Table 1). In order to identify depression, a cut-off point of 35 was suggested for a general population (Schmitt et al. 2006). According to that definition, $11 \%$ of men and $18 \%$ of women within our study population show a clinically relevant severity of depressive symptoms. As we are directly interested in the variation of depressive symptoms, we use the BDI-V as a continuous scale in our analyses. The internal consistency proves to be very good. Cronbach's alpha in this scale is $\alpha=0.920$ (among women $\alpha=0.921$; among men $\alpha=0.918$ ).

\subsubsection{Gender-dominated occupations}

There are several different approaches to assess gender segregation among occupations. The pattern of gender segregation becomes visible by showing the distribution and concentra-

${ }^{2}$ Missing data on one or two items were imputed by arithmetic mean values. tion of men and women in all occupations. As a result, a differentiation between male-dominated, female-dominated and gender-integrated occupations is possible. Different limits can be applied to determine these three categories (Achatz 2008). In order to create a measure for gender segregation for the lidA participants, we use the official employment statistics for 2011 (Statistik der Bundesagentur für Arbeit 2012). The information on occupations is provided in the first three digits of the German occupational classification scheme 88 (KldB 88). As fewer women than men are employed and thus included in the official statistics, women are weighted to gain equal proportions of men and women. A share of $80 \%$ of men or women per occupation is used to determine domination of one gender, which is a relatively strict requirement. Gender-integrated professions comprise a proportion of men and women from $21 \%$ to $79 \%$. Then, these indicators are assigned to the occupations of the lidA participants.

\subsubsection{Effort-reward imbalance}

As a measure of work stress, we use the effort-reward imbalance (ERI) model (Siegrist et al. 2004). The ERI questionnaire allows calculating three sub-scales: 'efforts' (6 items), 'rewards' (11 items) and 'overcommitment' (6 items). We calculate the effort-reward imbalance ratio (ERI ratio) by dividing the sub-scales 'efforts' and 'rewards' and adding a weighting factor for different item numbers of these subscales. The six items of 'overcommitment' are included as a total score ranging from 6 to 24 .

\subsubsection{Work-family conflict}

To assess work-family imbalance, the work-family conflict scale from the short version of the Copenhagen Psychosocial Questionnaire is applied (Pejtersen et al. 2010). The two questions were translated into two German statements for this purpose. The scale consists of two items that emphasise the two aspects of time and energy, and measures the direction of the conflict from work to private life. ${ }^{3}$ Answers to both items are made on a four-point response format from 1 (no, not at all) to 4 (yes, certainly) and are transformed to a value range from 0 (no, not at all) to 100 (yes, certainly). The work-family conflict is determined by the arithmetic mean of both items.

\subsubsection{Other variables}

In addition, we include variables in our analysis to adjust for age, socio-economic status (vocational level and occu-

\footnotetext{
${ }^{3} 1$. "My work drains so much of my energy that it has a negative effect on my private life.", 2. "My work takes so much of my time that this has a negative effect on my private life."
} 
pational status), employment status (full-time, part-time, marginal employment), household characteristics (children under the age of 14 and partner's employment status) as well as for further social resources (social isolation) (cf. Table 1).

\subsection{Statistical methods}

We use data of the first wave of the lidA study, thus crosssectional data. Our dependent variable "depressive symptoms" is treated as continuous. According to our research question, we first compare the mean values for depressive symptoms by occupational gender segregation using $t$-tests. In a second step, we use a multiple linear regression analysis to test our assumptions on the relationship between occupational gender segregation and depressive symptoms adjusting for further variables. In order to test for potential interaction effects, we include multiplicative interaction terms. Since there are indications for heteroskedasticity, we use robust standard errors in all presented models (Allison 1999). In order to consider the described gender differences as well as the high proportion of women working part-time in Germany, all models are estimated separately for men, full-time working women and part-time working women. Statistical analyses are performed using STATA v 13.1.

\section{Results}

\subsection{Descriptive overview}

In general, our study sample reflects the overall employment situation of men and women in Germany. ${ }^{4}$ The majority of males work full-time (96\%) and only few men work parttime $(3 \%)$ or are in marginal employment $(1 \%)$. Among women, there is an almost equal share in full-time employment (44\%) and part-time employment (47\%). Another 9\% of females are in marginal employment. Therefore, in the following, we differentiate by gender as well as by full-time employment versus part-time and marginal employment for women.

As can be seen in Table 1 , in our sample nearly $6 \%$ of full-time working women and almost $3 \%$ of part-time working women work in a profession which is male-dominated. Women in our sample who work in male-dominated occupations mostly work in the field of transport and logistics or production (e.g., warehouse and production assistants). With regard to males, nearly $4 \%$ of men work in a profession which is female-dominated. Men working in female-

\footnotetext{
${ }^{4}$ In Germany, most men work full-time, while women often work parttime, in particular women older than 35 years (Vogel 2009). The main reason for that is certainly the possibility to balance work and family within part-time or marginal employment (e.g. Drobnič et al. 1999).
}

dominated occupations mostly work in the health sector (e.g., nurse). Complementary, about $51 \%$ of men work in a profession which is male-dominated (mainly professions in the field of raw materials extraction, production and manufacturing) and nearly $29 \%$ of full-time working women and about $39 \%$ of part-time working women work in a profession which is female-dominated (mainly in healthcare and social occupations). The remaining proportion works in gender-integrated professions (mainly in office occupations and in the financial service sector).

Table 2 shows the mean values for depressive symptoms separately for men, full-time working women and women not working full-time, and separated by the level of occupational gender segregation. First, the mean of the total value for depressive symptoms is significantly enhanced for women as compared to men, which is in accordance with the literature (cf. Table 2). As can be seen, the average values for depressive symptoms by gender segregation show slightly higher means for men in female-dominated occupations in comparison to male and integrated-gender segregation. Furthermore, higher mean values for part-time and full-time working women in male-dominated occupations can be determined in comparison to female and integratedgender segregation. According to independent-sample $t$-test, a significant gender difference can only be found for women in male-dominated occupations (working full-time and part-time/marginal employment) in comparison to women in female-dominated occupations. In men, no relationship between gender-dominated occupations and the severity of depressive symptoms can be detected (cf. Table 2).

With regard to further work-related factors by occupational gender segregation and possible interactions, the mean value of the ERI ratio is significantly lower for all women in integrated occupations as well as for full-time working women in male-dominated occupations in comparison to women working in female-dominated occupations. For men, the ERI ratio is slightly higher in female-dominated occupations, however not significantly higher. For part-time or marginally employed women, the mean values are significantly lower in male-dominated and integrated occupations with regard to overcommitment. For full-time working women, there is a lower mean value for overcommitment in male-dominated occupations. For men, the differences are only marginal.

The level of perceived work-family conflict is significantly higher among men in integrated occupations. In full-time working women, no significant difference regarding work-family conflict could be measured. The level of work-family conflict is higher for all full-time working women independently from the degree of occupational gender segregation. For part-time working women or marginal employed women, the level of work-family conflict is below the levels for men and full-time working women. 
Table 1 Sample characteristics $(N=5221)$. (Source: lidA, wave 1, 2011; own calculations)

\begin{tabular}{|c|c|c|c|}
\hline & \multicolumn{2}{|l|}{ Women $(N=2769)$} & \multirow[t]{2}{*}{$\operatorname{Men}(N=2452)$} \\
\hline & full-time $(N=1212)$ & $\begin{array}{l}\text { part-time/marginal em- } \\
\text { ployment }(N=1557)\end{array}$ & \\
\hline \multicolumn{4}{|l|}{ Occupational gender segregation } \\
\hline Male-dominated $(\geq 80 \%)(\%)$ & 5.86 & 2.63 & 50.57 \\
\hline Female-dominated ( $\geq 80 \%)(\%)$ & 28.88 & 38.79 & 4.20 \\
\hline Integrated $(\%)$ & 65.26 & 58.57 & 45.23 \\
\hline \multicolumn{4}{|l|}{ Birth year } \\
\hline Born $1959(\%)$ & 45.46 & 43.16 & 42.82 \\
\hline Born $1965(\%)$ & 54.54 & 56.84 & 57.18 \\
\hline \multicolumn{4}{|l|}{ Vocational level } \\
\hline No vocational training $(\%)$ & 4.74 & 6.53 & 4.40 \\
\hline Completed vocational training/education (\%) & 58.19 & 65.85 & 54.87 \\
\hline Craftsman/craftswoman, technical college (\%) & 17.37 & 11.32 & 17.02 \\
\hline University of applied sciences degree (\%) & 7.32 & 6.92 & 9.86 \\
\hline University degree (\%) & 12.39 & 9.38 & 13.85 \\
\hline \multicolumn{4}{|l|}{ Occupational status } \\
\hline Unskilled/semi-skilled blue-collar worker (\%) & 8.33 & 10.98 & 11.30 \\
\hline Skilled blue-collar worker/craftsman (\%) & 2.31 & 2.38 & 24.14 \\
\hline White-collar worker $(\%)$ & 42.90 & 58.06 & 20.84 \\
\hline Qualified white-collar worker (\%) & 46.45 & 28.58 & 43.72 \\
\hline \multicolumn{4}{|l|}{ Work stress } \\
\hline Effort-reward ratio Mean \pm SD (range) & $0.52 \pm 0.23(0.25-2.23)$ & $0.48 \pm 0.22(0.25-2.75)$ & $0.50 \pm 0.21(0.25-3.14)$ \\
\hline Overcommitment Mean \pm SD (range) & $14.28 \pm 4.38(6-24)$ & $12.97 \pm 4.37(6-24)$ & $13.32 \pm 4.25(6-24)$ \\
\hline Work-family conflict Mean \pm SD (range) & $41.52 \pm 28.18(0-100)$ & $27.22 \pm 26.23(0-100)$ & $37.67 \pm 28.08(0-100)$ \\
\hline \multicolumn{4}{|l|}{ Household characteristics } \\
\hline Not cohabiting with partner $(\%)$ & 31.11 & 16.70 & 17.82 \\
\hline Partner working full-time (\%) & 56.11 & 74.31 & 25.45 \\
\hline Partner working part-time/marginal employment (\%) & 2.39 & 2.31 & 41.27 \\
\hline Partner not employed (\%) & 10.40 & 6.68 & 15.46 \\
\hline Children under the age of $14(\%)$ & 10.31 & 28.71 & 32.71 \\
\hline Social Isolation Mean $\pm \mathrm{SD}$ (range) & $2.32 \pm 0.59(1-4)$ & $2.33 \pm 0.58(1-4)$ & $2.35 \pm 0.65(1-4)$ \\
\hline Depressive symptoms $\mathrm{Mean} \pm \mathrm{SD}$ (range) & $21.72 \pm 14.25(0-89)$ & $22.29 \pm 13.97(0-79)$ & $18.31 \pm 13.09(0-88)$ \\
\hline
\end{tabular}

\subsection{Multivariate analysis}

In the multivariate analysis (cf. Table 3), we first regress depressive symptoms on gender segregation $(1 \mathrm{a}, 1 \mathrm{~b}, 1 \mathrm{c})$, second, we regress depressive symptoms on the ERI ratio and gender segregation $(2 \mathrm{a}, 2 \mathrm{~b}, 2 \mathrm{c})$, and third, depressive symptoms on overcommitment and gender segregation ( $3 \mathrm{a}$, $3 \mathrm{~b}, 3 \mathrm{c})$. Fourth, we test for an effect of gender segregation and work-family conflict on depressive symptoms $(4 \mathrm{a}, 4 \mathrm{~b}$, $4 \mathrm{c})$. The next models $(5 \mathrm{a}, 5 \mathrm{~b}, 5 \mathrm{c} ; 6 \mathrm{a}, 6 \mathrm{~b}, 6 \mathrm{c})$ include all concepts simultaneously, whereas the last model is adjusted for further factors, for instance vocational level.

The upper half of Table 3 shows the results of regression analyses separately for women working full-time and parttime. Regarding the results of model $1 \mathrm{a}$ and $1 \mathrm{~b}$, we find a higher frequency of depressive symptoms among women in male-dominated occupations as compared to women working in female-dominated occupations for both women working in full-time employment and women working in part-time or marginal employment. Including the ERI ratio, the effect of working in female-dominated occupations becomes more clearly visible. For women in full-time employment, the frequency of depressive symptoms is also higher in integrated occupations as compared to women working in femaledominated occupations. However, the perceived imbalance is highly significantly related to depressive symptoms (cf. $2 \mathrm{a}, 2 \mathrm{~b}$, Table 3). Moreover, the variance explained increases considerably. This applies similarly to overcommitment (cf. 3a, 3b, Table 3). Adding the work-family conflict, again, as for ERI ratio and overcommitment, the overall variance explained increases considerably. As we can see, also perceived work-family conflict is strongly related to depressive symptoms (cf. 4a, 4b, Table 3). Including all variables simultaneously, the directions and significance levels of the most relationships persist and the overall variance explained increases for women working full-time or part-time. The effect of the ERI ratio decreases and becomes less significant (cf. 5a, 5b, Table 3). The persistence of the relationships observed is tested in the extended models containing further adjusting factors. Adjusting for further variables, 
Table 2 Mean values for depressive symptoms, ERI ratio, overcommitment and work-family conflict by occupational gender segregation. (Source: lidA, wave 1, 2011; own calculations)

\begin{tabular}{llll}
\hline & \multicolumn{2}{l}{ Occupational gender segregation Mean \pm SD (range) } \\
\cline { 2 - 4 } & Male-dominated & Female-dominated & Integrated \\
\hline Women: full-time ${ }^{a}(N=1212)$ & & $20.63 \pm 13.89$ & $21.91 \pm 14.09$ \\
Depressive symptoms & $25.09 \pm 17.15^{*}$ & $0.56 \pm 0.23$ & $0.51 \pm 0.23^{* * *}$ \\
ERI ratio & $0.50 \pm 0.21^{*}$ & $14.46 \pm 4.22$ & $14.30 \pm 4.44$ \\
Overcommitment & $13.24 \pm 4.36^{*}$ & $42.98 \pm 27.29$ & $40.83 \pm 28.40$ \\
Work-family conflict & $41.99 \pm 30.15$ & & $22.05 \pm 14.08$ \\
Women: part-time/marginal employment ${ }^{a}(N=1557)$ & & $22.35 \pm 13.72$ & $0.45 \pm 0.20^{* * *}$ \\
Depressive symptoms & $26.67 \pm 14.69 \dagger$ & $0.52 \pm 0.24$ & $12.73 \pm 4.33^{* *}$ \\
ERI ratio & $0.50 \pm 0.23$ & $13.44 \pm 4.40$ & $26.23 \pm 25.92 \dagger$ \\
Overcommitment & $11.54 \pm 4.10^{* *}$ & $28.83 \pm 26.85$ & $18.13 \pm 12.71$ \\
Work-family conflict & $25.52 \pm 23.01$ & & \\
Men $^{b}(N=2452)$ & & $19.71 \pm 12.37$ & $0.49 \pm 0.20$ \\
Depressive symptoms & $18.35 \pm 13.47$ & $0.53 \pm 0.20$ & $13.46 \pm 4.07 \dagger$ \\
ERI ratio & $0.50 \pm 0.22$ & $13.67 \pm 4.05$ & $39.24 \pm 27.72^{*}$ \\
Overcommitment & $13.16 \pm 4.41$ & $37.80 \pm 25.37$ & \\
Work-family conflict & $36.25 \pm 28.55$ & & \\
\hline
\end{tabular}

Mean values are tested for significant difference in comparison to:

${ }^{a}$ working in female-dominated occupations

${ }^{\mathrm{b}}$ working in male-dominated occupations using independent samples $t$-test

$\dagger p<0.1 ; * p<0.05 ; * * p<0.01 ; * * * p<0.001$

the directions of the relationships remain once more. The strength of the relationship between depressive symptoms and working in a male-dominated occupation weakens. For women working full-time, there is no longer a relationship between working in an integrated occupation and depressive symptoms. However, for women working full-time as well as for women working part-time, taking work stress and further adjusting factors into account, we find a persistent relationship between working in a male-dominated occupation and depressive symptoms (cf. 6a, 6b, Table 3).

The lower part of Table 3 presents the results for men (cf. $1 \mathrm{c}-6 \mathrm{c})$. For males, we cannot find a relationship between depressive symptoms and working in female-dominated occupations or in integrated occupations in comparison to those men working in male-dominated occupations in any regression model, whereas work stress shows a strong relation to depressive symptoms among males. Moreover, in comparison to the results for females, the ERI ratio plays a more important role for men examining the relationship between work-related factors and depressive symptoms. The levels of variance explained are higher for men and women working full-time than for women in part-time and marginal employment in all models except for the basic model only containing gender segregation. Thus, for women working part-time or in marginal employment, perceived work stress and also work-family conflict are less strongly related to current depressive symptoms.

In order to further investigate the interactions between our concepts of interest, we include multiplicative interac- tion terms between gender segregation and effort-reward imbalance, overcommitment as well as work-family conflict in addition to the models in Table 3 (cf. Table 4 and Table 5). In women working full-time, we find one significant interaction effect among the tested combinations: Women in male-dominated occupations in comparison to women in female-dominated occupations show an increasing risk of depressive symptoms with increasing ERI ratio. In women in part-time or marginal employment, we find that with increasing ERI ratio the risk of depressive symptoms is higher for women in integrated occupations in comparison to women in female-dominated occupations. For part-time working women, we also detect a significant interrelation between overcommitment and male-dominated occupations as well as for work-family conflict and integrated occupations (Table 4). Therefore, for women not working fulltime, we find an increasing risk of depressive symptoms with higher levels of overcommitment in male-dominated occupations and also with higher levels of work-family conflict in integrated professions in comparison to women in female-dominated occupations.

In men, as we introduce an interaction effect between gender segregation and effort-reward imbalance, we interestingly find a decreasing risk of developing depressive symptoms by increasing the ERI ratio for men working in female-dominated occupations in comparison to men working in maledominated occupations. As for the two dimensions of work stress (ERI ratio and overcommitment), we find a marginal interaction effect. Thus, in men, with increasing perceived 
Table 3 Results of OLS regression analysis with depressive symptoms as dependent variable. (Source: lidA, wave 1, 2011; own calculations)

\begin{tabular}{|c|c|c|c|c|c|c|}
\hline Women: full-time ${ }^{a}(N=1212)$ & $1 \mathrm{a}$ & $2 \mathrm{a}$ & $3 \mathrm{a}$ & $4 \mathrm{a}$ & $5 \mathrm{a}$ & $6 \mathrm{a}^{\mathrm{b}}$ \\
\hline \multicolumn{7}{|l|}{ Occupational gender segregation } \\
\hline Female-dominated & Ref. & Ref. & Ref. & Ref. & Ref. & Ref. \\
\hline Integrated & 0.043 & $0.084 * *$ & $0.050 \dagger$ & $0.057^{*}$ & $0.070^{*}$ & 0.046 \\
\hline Male-dominated & $0.074^{*}$ & $0.098 * *$ & $0.100 * *$ & $0.077^{*}$ & $0.100 * *$ & $0.060 \dagger$ \\
\hline \multicolumn{7}{|l|}{ Work stress } \\
\hline Effort-reward ratio & & $0.353 * * *$ & & & $0.134 * *$ & $0.109 * *$ \\
\hline Overcommitment & & & $0.415 * * *$ & & $0.236 * * *$ & $0.270 * * *$ \\
\hline Work-family conflict & & & & $0.396 * * *$ & $0.211 * * *$ & $0.200 * * *$ \\
\hline $\mathrm{R}^{2}$ & 0.005 & 0.128 & 0.176 & 0.161 & 0.232 & 0.283 \\
\hline $\begin{array}{l}\text { Women: part-time/marginal employment } t^{a, c} \\
(N=1557)\end{array}$ & $1 \mathrm{~b}$ & $2 \mathrm{~b}$ & $3 b$ & $4 \mathrm{~b}$ & $5 b$ & $6 b^{b}$ \\
\hline \multicolumn{7}{|l|}{ Occupational gender segregation } \\
\hline Female-dominated & Ref. & Ref. & Ref. & Ref. & Ref. & Ref. \\
\hline Integrated & -0.010 & 0.032 & 0.020 & 0.006 & 0.032 & 0.030 \\
\hline Male-dominated & $0.051 \uparrow$ & $0.051^{*}$ & $0.073 * *$ & $0.053^{*}$ & $0.066^{* *}$ & $0.057 *$ \\
\hline \multicolumn{7}{|l|}{ Work stress } \\
\hline Effort-reward ratio & & $0.304 * * *$ & & & $0.102 * *$ & $0.087 *$ \\
\hline Overcommitment & & & $0.381 * * *$ & & $0.242 * * *$ & $0.260 * * *$ \\
\hline Work-family conflict & & & & $0.334 * * *$ & $0.168 * * *$ & $0.154 * * *$ \\
\hline $\mathrm{R}^{2}$ & 0.003 & 0.090 & 0.141 & 0.109 & 0.174 & 0.202 \\
\hline $\operatorname{Men}^{a}(N=2452)$ & $1 \mathrm{c}$ & $2 \mathrm{c}$ & $3 \mathrm{c}$ & $4 \mathrm{c}$ & $5 \mathrm{c}$ & $6 \mathrm{c}^{\mathrm{b}}$ \\
\hline \multicolumn{7}{|l|}{ Occupational gender segregation } \\
\hline Male-dominated & Ref. & Ref. & Ref. & Ref. & Ref. & Ref. \\
\hline Integrated & -0.008 & -0.000 & -0.022 & -0.027 & -0.021 & 0.002 \\
\hline Female-dominated & 0.021 & 0.009 & 0.011 & 0.017 & 0.007 & 0.018 \\
\hline \multicolumn{7}{|l|}{ Work stress } \\
\hline Effort-reward ratio & & $0.372 * * *$ & & & $0.191 * * *$ & $0.165 * * *$ \\
\hline Overcommitment & & & $0.396 * * *$ & & $0.216 * * *$ & $0.244 * * *$ \\
\hline Work-family conflict & & & & $0.360 * * *$ & $0.171 * * *$ & $0.171 * * *$ \\
\hline $\mathrm{R}^{2}$ & 0.002 & 0.139 & 0.158 & 0.131 & 0.220 & 0.265 \\
\hline
\end{tabular}

${ }^{a}$ Models $1 \mathrm{a}, 1 \mathrm{~b}$ to $5 \mathrm{a}, 5 \mathrm{~b}$ are adjusted for cohort affiliation

${ }^{b}$ Models $6 \mathrm{a}, 6 \mathrm{~b}$ are additionally adjusted for cohort affiliation, vocational level, occupational status, employment status, household characteristics and social resources

'For women working part-time or in marginal employment all models are adjusted for marginal employment (cf. Appendix, Table 6)

Beta coefficients, $\dagger p<0.1 ; * p<0.05 ; * * p<0.01 ; * * * p<0.001$

imbalance between efforts and rewards also the level of overcommitment increases which leads to an increased risk of depressive symptoms. We detect no interaction effects between overcommitment and gender segregation or workfamily conflict and gender segregation for men (cf. Table 5).

\section{Discussion and concluding remarks}

The purpose of this study was to examine whether and to what extent working as a woman in a male-dominated occupation or working as a man in a female-dominated occupation is associated with a higher risk of depressive symptoms and whether these associations are independent of other work-related and non-work factors (e.g., work stress and work-family conflict). Additionally, interactions of occupa- tional gender segregation with work stress and work-family conflict in relation to depressive symptoms were investigated. The implications as well as strengths and limitations of our study results will be discussed in the following.

In line with other research in this area, our results indicate that among middle-aged employees in Germany, females show higher mean values of depressive symptoms than males. Drawing on Kanter's model (1993) and corresponding research results, it was assumed that working in occupations dominated by the opposite gender is related to the frequency of depressive symptoms. It was assumed that women in male-dominated and men in female-dominated occupations would report most depressive symptoms. According to our results, differences by occupational gender segregation in relation to depressive symptoms among males are markedly less pronounced than among females. 
Table 4 Results of OLS regression analysis with depressive symptoms as dependent variable and interaction effects-women. (Source: lidA, wave 1, 2011; own calculations)

\begin{tabular}{|c|c|c|c|c|}
\hline Women: full-time ${ }^{a}(N=1212)$ & $7 \mathrm{a}$ & $8 \mathrm{a}$ & $9 \mathrm{a}$ & $10 \mathrm{a}$ \\
\hline \multicolumn{5}{|l|}{ Occupational gender segregation } \\
\hline Female-dominated & Ref. & Ref. & Ref. & Ref. \\
\hline Integrated & $0.070 * *$ & $0.068 * *$ & $0.074 * *$ & $0.068 *$ \\
\hline Male-dominated & $0.099 * *$ & $0.099 * *$ & $0.097 * *$ & $0.099 * *$ \\
\hline \multicolumn{5}{|l|}{ Work stress } \\
\hline Effort-reward ratio & $0.128 \dagger$ & $0.133 * * *$ & $0.134 * * *$ & $0.116^{*}$ \\
\hline Overcommitment & $0.238 * * *$ & $0.225^{* * *}$ & $0.237 * * *$ & $0.234 * * *$ \\
\hline Work-family conflict & $0.211 * * *$ & $0.211 * * *$ & $0.225 * * *$ & $0.214 * * *$ \\
\hline \multicolumn{5}{|l|}{ Interactions } \\
\hline Female-dominated $\mathrm{x}$ Effort-reward ratio & Ref. & & & \\
\hline Integrated $\mathrm{x}$ Effort-reward ratio & -0.012 & & & \\
\hline Male-dominated x Effort-reward ratio & $0.067 \dagger$ & & & \\
\hline Female-dominated x Overcommitment & & Ref. & & \\
\hline Integrated x Overcommitment & & 0.014 & & \\
\hline Male-dominated x Overcommitment & & -0.001 & & \\
\hline Female-dominated $\mathrm{x}$ Work-family conflict & & & Ref. & \\
\hline Integrated x Work-family conflict & & & -0.021 & \\
\hline Male-dominated x Work-family conflict & & & 0.009 & \\
\hline Effort-reward ratio x Overcommitment & & & & 0.032 \\
\hline $\mathrm{R}^{2}$ & 0.237 & 0.233 & 0.233 & 0.233 \\
\hline $\begin{array}{l}\text { Women: part-time/marginal employment }{ }^{a, b} \\
(N=1557)\end{array}$ & $7 \mathrm{~b}$ & $8 \mathrm{~b}$ & $9 \mathrm{~b}$ & $10 \mathrm{~b}$ \\
\hline \multicolumn{5}{|l|}{ Occupational gender segregation } \\
\hline Female-dominated & Ref. & Ref. & Ref. & Ref. \\
\hline Integrated & 0.035 & 0.034 & $0.043 \dagger$ & 0.031 \\
\hline Male-dominated & $0.065 * *$ & $0.083 * *$ & $0.077 * * *$ & $0.067 * *$ \\
\hline \multicolumn{5}{|l|}{ Work stress } \\
\hline Effort-reward ratio & 0.043 & $0.102 * *$ & $0.108 * *$ & $0.126^{* *}$ \\
\hline Overcommitment & $0.239 * * *$ & $0.205 * * *$ & $0.241 * * *$ & $0.236^{* * *}$ \\
\hline Work-family conflict & $0.171 * * *$ & $0.170 * * *$ & $0.104 *$ & $0.167 * * *$ \\
\hline \multicolumn{5}{|l|}{ Interactions } \\
\hline Female-dominated $\mathrm{x}$ Effort-reward ratio & Ref. & & & \\
\hline Integrated $\mathrm{x}$ Effort-reward ratio & $0.079 \dagger$ & & & \\
\hline Male-dominated x Effort-reward ratio & 0.021 & & & \\
\hline Female-dominated $\mathrm{x}$ Overcommitment & & Ref. & & \\
\hline Integrated x Overcommitment & & 0.040 & & \\
\hline Male-dominated x Overcommitment & & $0.044 \dagger$ & & \\
\hline Female-dominated $\mathrm{x}$ Work-family conflict & & & Ref. & \\
\hline Integrated x Work-family conflict & & & $0.037^{*}$ & \\
\hline Male-dominated x Work-family conflict & & & 0.077 & \\
\hline Effort-reward ratio x Overcommitment & & & & -0.046 \\
\hline $\mathrm{R}^{2}$ & 0.177 & 0.175 & 0.177 & 0.175 \\
\hline
\end{tabular}

${ }^{a}$ All models are adjusted for cohort affiliation. Continuous variables are centred

${ }^{b}$ For women working part-time or in marginal employment, all models are additionally adjusted for marginal employment

Beta coefficients, $\dagger p<0.1 ;{ }^{*} p<0.05 ; * * p<0.01 ; * * p<0.001$, robust standard errors

The findings of our multivariate analyses provide crosssectional evidence that only women in male-dominated occupations have a higher incidence rate of depressive symptoms in comparison to female-dominated occupations, whereas self-rated depressive symptoms in men were not affected by gender segregation. Among women, a relationship between working in male-dominated occupations and depressive symptoms can be found for full-time working women as well as for part-time working women. Furthermore, for women, we find the extent of work (full-time vs. part-time and marginal employment) to be an important differentiation factor.

Our findings can be explained with existing research results. Women in male-dominated occupations mainly 
Table 5 Results of OLS regression analysis with depressive symptoms as dependent variable and interaction effects-men. (Source: lidA, wave 1, 2011; own calculations)

\begin{tabular}{|c|c|c|c|c|}
\hline $\operatorname{Men}^{a}(N=2452)$ & $7 \mathrm{c}$ & $8 \mathrm{c}$ & $9 \mathrm{c}$ & $10 \mathrm{c}$ \\
\hline \multicolumn{5}{|c|}{ Occupational gender segregation } \\
\hline Male-dominated & Ref. & Ref. & Ref. & Ref. \\
\hline Integrated & 0.015 & 0.010 & 0.007 & 0.009 \\
\hline Female-dominated & -0.021 & -0.021 & -0.020 & -0.020 \\
\hline \multicolumn{5}{|l|}{ Work stress } \\
\hline Effort-reward ratio & $0.208 * * *$ & $0.192 * * *$ & $0.191 * * *$ & $0.156^{* * *}$ \\
\hline Overcommitment & $0.217 * * *$ & $0.219 * * *$ & $0.216^{* * *}$ & $0.224 * * *$ \\
\hline \multicolumn{5}{|l|}{ Interactions } \\
\hline $\begin{array}{l}\text { Male-dominated } \mathrm{x} \\
\text { Effort-reward ratio }\end{array}$ & Ref. & & & \\
\hline $\begin{array}{l}\text { Integrated x Effort- } \\
\text { reward ratio }\end{array}$ & -0.011 & & & \\
\hline $\begin{array}{l}\text { Female-dominated } \mathrm{x} \\
\text { Effort-reward ratio }\end{array}$ & $-0.048 * *$ & & & \\
\hline $\begin{array}{l}\text { Male-dominated } \mathrm{x} \\
\text { Overcommitment }\end{array}$ & & Ref. & & \\
\hline $\begin{array}{l}\text { Integrated } \mathrm{x} \\
\text { Overcommitment }\end{array}$ & & 0.004 & & \\
\hline $\begin{array}{l}\text { Female-dominated } \mathrm{x} \\
\text { Overcommitment }\end{array}$ & & -0.030 & & \\
\hline $\begin{array}{l}\text { Male-dominated } \mathrm{x} \\
\text { Work-family conflict }\end{array}$ & & & Ref. & \\
\hline $\begin{array}{l}\text { Integrated x Work- } \\
\text { family conflict }\end{array}$ & & & -0.016 & \\
\hline $\begin{array}{l}\text { Female-dominated } \mathrm{x} \\
\text { Work-family conflict }\end{array}$ & & & 0.011 & \\
\hline $\begin{array}{l}\text { Effort-reward ratio } \mathrm{x} \\
\text { Overcommitment }\end{array}$ & & & & $0.061 \dagger$ \\
\hline$\underline{\mathrm{R}^{2}}$ & 0.222 & 0.220 & 0.220 & 0.222 \\
\hline
\end{tabular}

demonstrate a greater probability of occurrence of psychological health problems and mood disorders, like depression, than in female-dominated occupations (Mota et al. 2012). One reason for this could be that females perceive more job demands, less flexibility, lack of acceptance and self-efficacy or even gender harassment and thus develop higher stress levels in gender-segregated, particularly in male-dominated, professions (Bartol et al. 1992; Germain et al. 2012; Hochwarter et al. 1995; Leskinen et al. 2011). Potential stress factors for women in male-dominated occupations can also be divided in psychological (e.g., selfdoubt, performance pressure or scepticism of their abilities by others) and physical (e.g., ineffective physical conditioning, ill-fitting personal protective equipment) stressors (Shuster 2000). As stress plays an important role in developing depressive symptoms in females (Harkness et al. 2010), it is likely that work stress and its effects on depressive symptoms in women are most pronounced in male-domi- nated occupations. Another reason for the existing significant effect of gender segregation on depressive symptoms in women in our study could be that females generally have worse health perceptions and disease resistance because of more negative emotions than males (Anson et al. 1993).

The missing significant effect in female-dominated and integrated occupations on depressive symptoms in men goes along with Kanter's theory (1993) which implies that male minorities in female-dominated occupations report reduced negative effects. One reason is that men are mainly evaluated based on their experience and skills. This outcome indicates that gender proportions alone are not fully responsible for the negative health effects of being a minority. Thus, working in occupations dominated by the opposite gender explains only a certain proportion of gender differences in health. Moreover, working in female-dominated and integrated professions may lead to a positive outcome in terms of a higher perceived job control in male employees (Hochwarter et al. 1995). A few studies report that males even feel more comfortable working with women and benefit from their minority status in terms of, for example, perceived increased leadership (Simpson 2004).

Concerning the association of occupational gender segregation and work-family conflict on depressive symptoms, it becomes evident that there are hardly any or only marginally significant results. Thus, it can be assumed that a negative work-to-family spillover has no relevant influence on depressiveness in different gender-segregated occupations among both genders. With regard to the association of occupational gender segregation and work stress on depressive symptoms, for men in female-dominated professions, we find a decreasing risk of depressive symptoms with increasing ERI ratio. For full-time working women in male-dominated occupations, we find an increased risk of depressive symptoms with a greater ERI ratio whereas for not full-time working women, we find a higher risk of depressive symptoms with an enhanced ERI ratio for those working in integrated occupations. Thus, the situation as a minority in an occupation seems to be very different for men and women and also differs between women working full- or part-time.

\subsection{Strengths and limitations}

Among the strengths of the present investigation, the high representativeness of the study for the two age cohorts of the dependently employed basic sample needs to be mentioned. The sampling process was based on data from the Integrated Employment Biographies including broad information from all employees subject to social insurance contributions (Dorner et al. 2010; Schröder et al. 2013). Thus, an extensive selectivity analysis was performed which did not reveal any significant deviations of our study cohort from the basic sample (Hasselhorn et al. 2014; Schröder 
et al. 2013). Furthermore, the intrinsic validity of our study is high. Mainly successfully tested scales like ERI and BDI-V were included.

Yet, some limitations of our study need to be discussed. The first limitation refers to the cross-sectional character of our analysis. Accordingly, reversed causality cannot be excluded. Examining health outcomes with cross-sectional data, researchers always have to challenge causality in observed associations. Selection bias is a common problem of population-based studies. With employed populations under observation, like in the lidA study, health related selection out of the labour market is most prominent. However, we aimed to describe the situation of those currently employed.

Furthermore, by using subjectively reported information as predictor and as outcome variables, influences of personal factors of the study participants, such as neuroticism on the reported findings, cannot be excluded. Regarding missing values in our data set, we used complete case analyses. Especially for depressiveness we certainly cannot exclude that the probability of missing values might have been more frequent in higher levels of depressiveness. This could have introduced some bias in our results.

\subsection{Concluding remarks}

Our results indicate that women in male-dominated occupations show higher levels of depressive symptoms, while for men, we find no direct relationship between working in female-dominated occupations and depressive symptoms. Further research is needed to shed more light on the question why women in male-dominated occupations tend to be more depressed. The further work-related factors under observation (work stress and work-family conflict) only partly explain a more vulnerable situation of women in male-dominated occupations that can lead to depressive symptoms. Investigating further risks and protective factors regarding women in male-dominated occupations could be worthwhile under aspects of work-related health promotion and prevention.

In future research regarding occupational gender segregation as a stress factor, it might be reasonable to look at specific occupations in particular to better understand the mechanism of gender segregation becoming a stress factor. Furthermore, beside depressive symptoms, it would be interesting to focus on further mental and physical health or disease outcomes. Previous findings imply that health differences between male- and female-dominated workplaces in either male- or female-dominated professions exist (Mastekaasa 2005). In our study, we only focused on the degree of gender segregation within occupational groups, while gender distribution regarding the workplace was not taken into account. Thus, further research should also consider the proportion of male and female employees at the workplace.

\section{Kurzfassung}

Seit Jahrzehnten sind geschlechtsspezifische Unterschiede im Auftreten von Depressionen zum Nachteil von Frauen bekannt. Psychische Erkrankungen sind in Deutschland der Hauptgrund für den Übergang in die Erwerbsminderungsrente. Daneben zeigt sich, dass sich der Übergang in die Erwerbsminderungsrente aufgrund psychischer Erkrankungen auch in Abhängigkeit vom Beruf unterscheidet. Weiterhin stellt die horizontale wie vertikale Geschlechtersegregation ein persistentes Merkmal vieler Arbeitsmärkte dar. Die vorliegende Studie betrachtet vor diesem Hintergrund, ob die horizontale Geschlechtersegregation, die Tätigkeit in einem Männerberuf für Frauen oder in einem Frauenberuf für Männer mit einem erhöhten Risiko für Depressivität zusammenhängt und weiterhin ob diese Zusammenhänge unabhängig sind von weiteren Belastungsfaktoren der Erwerbssituation wie beruflichen Gratifikationskrisen und Work-Family Konflikt. Zudem wird überprüft, ob Interaktionen zwischen dem Grad der Geschlechtersegregation im ausgeübten Beruf und den weiteren Belastungsfaktoren der Erwerbssituation in Bezug auf Depressivität bestehen.

Zur Formulierung von Annahmen wird Bezug zu bisherigen Forschungsergebnissen genommen sowie zur Theorie von Kanter, die die besondere Situation Beschäftigter als Minorität in einem Beruf beschreibt. So kann angenommen werden, dass die Tätigkeit in einem Beruf als Minderheit, als Frau in einem Männerberuf oder als Mann in einem Frauenberuf, ein besonderes Belastungsmerkmal darstellen kann, das negativ mit der mentalen Gesundheit verknüpft ist. Weiterhin ist anzunehmen, dass sich für die betrachteten Zusammenhänge Unterschiede zwischen Männern und Frauen zeigen. Zudem müssen die angenommenen Zusammenhänge für weitere mögliche Belastungsfaktoren adjustiert werden.

Als Datengrundlage für die empirischen Analysen dienen die Daten der ersten Welle der lidA-Studie. Zur Abbildung von Depressivität wird das vereinfachte Beck-DepressionsInventar genutzt. Ein Anteil von 80 Prozent pro Berufsangabe wird verwendet, um die Dominanz eines Geschlechts in einem Beruf zu bestimmen. Demnach gelten Berufe mit einem Frauenanteil von 80 Prozent und mehr als Frauenberufe, während Berufe mit einem Männeranteil von 80 Prozent und mehr als Männerberufe gelten. Die dazwischenliegenden Berufe werden als geschlechterintegrierte Berufe eingestuft. Weiterhin werden die Skalen zur Messung beruflicher Gratifikationskrisen sowie des Work-Family Konflikts herangezogen. Als weitere Kontrollvariablen werden die Kohortenzugehörigkeit, das berufliche Ausbildungsniveau, die Stellung im Beruf, Haushaltscharakteristika sowie der Grad sozialer Iso- 
lation berücksichtigt und für Frauen außerdem der Umfang der Erwerbstätigkeit. Eine empirische Überprüfung dieser Zusammenhänge findet für Frauen und Männer getrennt statt. Als statistische Verfahren werden Mittelwertvergleiche sowie multiple lineare Regressionen angewendet.

Im Ergebnis zeigt sich, dass Frauen in männerdominierten Berufen signifikant höhere Depressivitätswerte aufweisen, auch unter Kontrolle weiterer Faktoren. Dies bestätigt die aufgestellten Annahmen zumindest für Frauen und geht einher mit vorliegenden Forschungsbefunden für andere Länder. Für Männer in frauendominierten Berufen zeigt sich kein Zusammenhang zu höheren Depressivitätswerten. Die weiteren Faktoren, die in der Analyse berücksichtigt werden, Arbeitsstress und Work-Family Konflikt, stehen in einem signifikanten Zusammenhang zu Depressivität, können aber nur begrenzt die vulnerablere Situation von Frauen in männerdominierten Berufen erklären. Weiterhin können signifikante Interaktionen zwischen beruflicher Geschlechtersegregation und wahrgenommenen Arbeitsbelastungen für Frauen und Männer in Bezug auf Depressivität berichtet werden. Insgesamt scheint sich die Situation als Minorität in einem Beruf für Männer und Frauen unterschiedlich zu gestalten. Für Frauen unterscheidet sich dies außerdem in Abhängigkeit vom Umfang der Erwerbstätigkeit.

Einschränkend ist anzumerken, dass die vorliegende Untersuchung ein Querschnittsdesign hat und so gewisse Verzerrungen nicht ausgeschlossen werden können. Die Studie beschreibt die aktuelle Situation Beschäftigter der betrachteten Altersgruppe im Hinblick auf die interessierenden Faktoren der Erwerbssituation und deckt Hinweise auf bestehende Zusammenhänge zu Depressivität auf. Ausblickend scheint eine anknüpfende tiefergehende Betrachtung bestehender Risiken und Schutzfaktoren für Frauen in männlich dominierten Berufen in Hinblick auf die mentale Gesundheit sinnvoll. Eine detailliertere Betrachtung einzelner Berufe könnte dazu beitragen, konkrete Mechanismen aufzudecken, die dazu führen, dass die Tätigkeit von Frauen in Männerberufen mental belastender ist. Zudem werden in der vorliegenden Studie lediglich die Anteile von Frauen und Männern je Beruf als Maß der Geschlechtersegregation herangezogen. Weiterführend ist es denkbar auch den Anteil von Frauen und Männern in Betrieben als Maß der Geschlechtersegregation des Arbeitsplatzes heranzuziehen.

Acknowledgments We wish to thank Nancy Reims and Anita Tisch for their helpful comments and we are grateful to the two anonymous referees for their useful suggestions and notes which helped to improve our paper. We thank the Pearson Assessment \& Information $\mathrm{GmbH}$ for the permission to use the BDI-V-questionnaire. The sole responsibility for the content of this publication lies with the authors.

Funding The lidA project is funded by the German Federal Ministry of Education and Research (BMBF) under the project numbers 01 ER 0806, 01 ER 0825, 01 ER 0827.

\section{Appendix}

Table 6 Full results of OLS regression analysis with depressive symptoms as dependent variable. (Source: lidA, wave 1, 2011; own calculations)

\begin{tabular}{|c|c|c|c|}
\hline & $\begin{array}{l}\text { Women: } \\
\text { full-time } \\
(N=1212)\end{array}$ & $\begin{array}{l}\text { Women: part- } \\
\text { time/marginal } \\
\text { employment } \\
(N=1557)\end{array}$ & $\begin{array}{l}\text { Men } \\
(N=2452)\end{array}$ \\
\hline & $6 \mathrm{a}$ & $6 \mathrm{~b}$ & $6 \mathrm{c}$ \\
\hline \multicolumn{4}{|l|}{ Birth year } \\
\hline $\begin{array}{l}\text { Born } 1965 \text { (Ref. born } \\
\text { 1959) }\end{array}$ & 0.010 & 0.014 & 0.022 \\
\hline \multicolumn{4}{|c|}{ Occupational gender segregation } \\
\hline Female-dominated & Ref. & Ref. & 0.018 \\
\hline Integrated & 0.044 & 0.029 & 0.004 \\
\hline Male-dominated & $0.059 \dagger$ & $0.057^{*}$ & Ref. \\
\hline \multicolumn{4}{|l|}{ Work stress } \\
\hline Effort-reward ratio & $0.093 *$ & $0.073 *$ & $0.148 * * *$ \\
\hline Overcommitment & $0.276^{* * *}$ & $0.265^{* * *}$ & $0.251 * * *$ \\
\hline Work-family conflict & $0.205^{* * *}$ & $0.157 * * *$ & $0.175^{* * *}$ \\
\hline \multicolumn{4}{|l|}{ Vocational level } \\
\hline No vocational training & $0.056^{*}$ & 0.031 & 0.024 \\
\hline $\begin{array}{l}\text { Completed vocational } \\
\text { training/education }\end{array}$ & Ref. & Ref. & Ref. \\
\hline $\begin{array}{l}\text { Craftsman/craftswoman, } \\
\text { technical college }\end{array}$ & 0.020 & 0.010 & -0.001 \\
\hline $\begin{array}{l}\text { University of applied sci- } \\
\text { ences degree }\end{array}$ & -0.023 & 0.027 & -0.003 \\
\hline University degree & -0.013 & 0.035 & 0.012 \\
\hline Other & 0.044 & -0.002 & 0.005 \\
\hline \multicolumn{4}{|l|}{ Occupational status } \\
\hline $\begin{array}{l}\text { Unskilled/semi-skilled } \\
\text { blue-collar worker }\end{array}$ & 0.033 & 0.011 & $0.041 \dagger$ \\
\hline $\begin{array}{l}\text { Skilled blue-collar } \\
\text { worker/craftsman }\end{array}$ & -0.015 & $-0.050^{* *}$ & 0.003 \\
\hline White-collar worker & Ref. & Ref. & Ref. \\
\hline $\begin{array}{l}\text { Qualified white-collar } \\
\text { worker }\end{array}$ & $-0.122 * * *$ & $-0.074 * *$ & $-0.072 * *$ \\
\hline $\begin{array}{l}\text { Marginal employment (for } \\
\text { men: part time/marginal } \\
\text { employment) }\end{array}$ & 1 & $0.072 * *$ & $0.060^{* *}$ \\
\hline \multicolumn{4}{|l|}{ Household characteristics } \\
\hline $\begin{array}{l}\text { Children under the age of } \\
14 \text { (Ref. no) }\end{array}$ & -0.022 & 0.017 & 0.009 \\
\hline $\begin{array}{l}\text { Not cohabiting with } \\
\text { partner }\end{array}$ & Ref. & Ref. & Ref. \\
\hline Partner working full-time & $-0.121 * * *$ & $-0.122 * * *$ & $-0.134 * * *$ \\
\hline $\begin{array}{l}\text { Partner working part-time/ } \\
\text { marginal employment }\end{array}$ & $-0.036^{*}$ & -0.025 & $-0.143 * * *$ \\
\hline Partner not employed & -0.036 & $-0.067 *$ & $-0.096 * * *$ \\
\hline Social isolation & $0.097 * * *$ & $0.082 * * *$ & $0.119^{* * *}$ \\
\hline $\mathrm{R}^{2}$ & 0.281 & 0.200 & 0.261 \\
\hline
\end{tabular}

Beta coefficients, $\uparrow p<0.1 ;{ }^{*} p<0.05 ;{ }^{* *} p<0.01 ; * * * p<0.001$ 


\section{References}

Achatz, J.: Geschlechtersegregation im Arbeitsmarkt. In: Abraham, M., Hinz, T. (eds.) Arbeitsmarktsoziologie. Probleme, Theorien, empirische Befunde, pp. 263-301. VS Verlag für Sozialwissenschaften, Wiesbaden (2008)

Allen, T.D., Herst, D.E.L., Bruck, C.S., Sutton, M.: Consequences associated with work-to-family conflict: A review and agenda for future research. J. Occup. Health Psychol. 5(2), 278-308 (2000)

Allison, P.D.: Multiple Regression. A Primer. Pine Forge Press, Thousand Oaks (1999)

Amstad, F.T., Meier, L.L., Fasel, U., Elfering, A., Semmer, N.K.: A meta-analysis of work-family conflict and various outcomes with a special emphasis on cross-domain versus matching-domain relations. J. Occup. Health Psychol. 16(2), 151-169 (2011)

Anson, O., Paran, E., Neumann, L., Chernichovsky, D.: Gender differences in health perceptions and their predictors. Soc. Sci. Med. 36(4), 419-427 (1993)

Bartol, C.R., Bergen, G.T., Volckens, J.S., Knoras, K.M.: Women in small-town policing: Job performance and stress. Crim. Justice Behav. 19(3), 240-259 (1992)

Bathman, L.M., Almond, J., Hazi, A., Wright, B.J.: Effort-reward imbalance at work and pre-clinical biological indices of ill-health: The case for salivary immunoglobulin A. Brain Behav. Immun. 33, 74-79 (2013)

Beck, A.T., Steer, R.A., Carbin, M.G.: Psychometric properties of the beck depression inventory: Twenty-five years of evaluation. Clin. Psychol. Rev. 8(1), 77-100 (1988)

Beck-Gernsheim, E.: Männerrolle, Frauenrolle - aber was steht dahinter? Soziologische Perspektiven zur Arbeitsteilung und Fähigkeitsdifferenzierung zwischen den Geschlechtern. In: Eckert, R. (ed.) Geschlechtsrollen und Arbeitsteilung aus soziologischer Sicht, pp. 165-201. C.H.Beck, München (1979)

Bildt, C., Michélsen, H.: Gender differences in the effects from working conditions on mental health: a 4-year follow-up. Int. Arch. Occup. Environ. Health. 75(4), 252-258 (2002)

Blackburn, R.M., Browne, J., Brooks, B., Jarman, J.: Explaining gender segregation. Brit. J. Sociol. 53(4), 513-536 (2002)

Bond, J.T., Galinsky, E., Swanberg, J.E.: The National Study of the Changing Workforce 1997. No. 2. Families and Work Institute, New York (1998)

Bryngelson, A., Bacchus Hertzman, J., Fritzell, J.: The relationship between gender segregation in the workplace and long-term sickness absence in Sweden. Scand. J. Public Health. 39(6), 618-626 (2011)

Busch, A.: Die berufliche Geschlechtersegregation in Deutschland. Springer Fachmedien, Wiesbaden (2013)

Byron, K.: A meta-analytic review of work-family conflict and its antecedents. J. Vocat. Behav. 67(2), 169-198 (2005)

Chandola, T., Britton, A., Brunner, E., Hemingway, H., Malik, M., Kumari, M., Badrick, E., Kivimaki, M., Marmot, M.: Work stress and coronary heart disease: what are the mechanisms? Eur. Heart J. 29(5), 640-648 (2008)

Charles, M.: Deciphering sex segregation: Vertical and horizontal inequalities in ten national labor markets. Acta. Sociol. 46(4), 267287 (2003)

Cramm, C., Blossfeld, H.-P., Drobnič, S.: Die Auswirkungen der Doppelbelastung durch Familie und Beruf auf das Krankheitsrisiko von Frauen. Z. Soziol. 27(5), 341-357 (1998)

Deutsche Rentenversicherung Bund (ed.) Rentenversicherung in Zeitreihen. Ausgabe 2012. Berlin (2012)

Dorner, M., Heining, J., Jacobebbinghaus, P., Seth, S.: The sample of integrated labour market biographies. Schmollers Jahrbuch. 130(4), 599-608 (2010)
Dragano, N., He, Y., Moebus, S., Jöckel, K.-H., Erbel, R., Siegrist, J.: Two models of job stress and depressive symptoms. Soc. Psychiatry Psychiatr. Epidemiol. 43(1), 72-78 (2008)

Drobnič, S., Blossfeld, H.-P., Rohwer, G.: Dynamics of women's employment patterns over the family life course. A comparison of the United States and Germany. J. Marriage Fam. 61(1), 133-146 (1999)

Eagle, B.W., Miles, E.W., Icenogle, M.L.: Interrole conflicts and the permeability of work and family domains: Are there gender differences? J. Vocat. Behav. 50, 168-184 (1997)

Evans, O., Steptoe, A.: The contribution of gender-role orientation, work factors and home stressors to psychological well-being and sickness absence in male- and female-dominated occupational groups. Soc. Sci. Med. 54(4), 481-492 (2002)

Federal Statistical Office: Fachserie 1 Reihe 4.1.2. Mikrozensus. Bevölkerung und Erwerbstätigkeit. Beruf, Ausbildung und Arbeitsbedingungen der Erwerbstätigen in Deutschland. Wiesbaden (2012)

Frone, M.R.: Work-family balance. In: Quick, J.C., Tetrick, L.E. (eds.) Handbook of occupational health psychology, pp. 143-162. American Psychological Association, Washington DC (2003)

Frone, M.R., Russell, M., Cooper, M.L.: Prevalence of work-family conflict: Are work and family boundaries asymmetrically permeable? J. Organ. Behav. 13(7), 723-729 (1992)

Frone, M.R., Russell, M., Barnes, G.M.: Work-family conflict, gender, and health-related outcomes: A study of employed parents in two community samples. J. Occup. Health Psychol. 1(1), 57-69 (1996)

Galinsky, E., Aumann, K., Bond, J.T.: Times are changing: Gender and generation at work at home. In: Families and Work Institute (ed.), pp. 1-28. New York (2011)

Germain, M.-L., Herzog, M.J.R., Hamilton, P.R.: Women employed in male-dominated industries: lessons learned from female aircraft pilots, pilots-in-training and mixed-gender flight instructors. Hum. Resour. Dev. Int. 15(4), 435-453 (2012)

Godin, I., Kittel, F.: Differential economic stability and psychosocial stress at work: associations with psychosomatic complaints and absenteeism. Soc. Sci. Med. 58(8), 1543-1553 (2004)

Godin, I., Kittel, F., Coppieters, Y., Siegrist, J.: A prospective study of cumulative job stress in relation to mental health. BMC Public Health. 5, 67-77 (2005)

Grandey, A.A., Cropanzano, R.: The conservation of resources model applied to work-family conflict and strain. J. Vocat. Behav. 54(2), 350-370 (1999)

Greenhaus, J.H., Beutell, N.J.: Sources of conflict between work and family roles. Acad. Manage. Rev. 10(1), 76-88 (1985)

Haines, V.Y., Marchand, A., Rousseau, V., Demers, A.: The mediating role of work-to-family conflict in the relationship between shiftwork and depression. Work Stress. 22(4), 341-356 (2008)

Harkness, K.L., Nazanin, A., Monroe, S.M., Slavich, G.M., Gotlib, I.H., Bagby, R.M.: Gender differences in life events prior to onset of major depressive disorder: The moderating effect of age. J. Abnorm. Psychol. 119(4), 791-803 (2010)

Hasselhorn, H.M., Peter, R., Rauch, A., Schröder, H., Swart, E., Bender, S., du Prel, J.B., Ebener, M., March, S., Trappmann, M., Steinwede, J., Müller, B.H.: Cohort profile: The lidA cohort study-a German cohort study on work, age, health and work participation. Int. J. Epidemiol., forthcoming (2014) [Epub ahead of print]

Hensing, G., Alexanderson, K.: The association between sex segregation, working conditions, and sickness absence among employed women. Occup. Environ. Med. 61(2), e7 (2004)

Hintsanen, M., Elovainio, M., Puttonen, S., Kivimäki, M., Koskinen, T., Raitakari, O., Keltikangas-Järvinen, L.: Effort-reward imbalance, heart rate, and heart rate variability: the cardiovascular risk in young finns study. Int. J. Behav. Med. 14(4), 202-212 (2007) 
Hochwarter, W., Perrewe, P., Dawkins, M.: Gender differences in perceptions of stress-related variables: Do the people make the place or does the place make the people? J. Manag. Issues. 7(1), 62-74 (1995)

Hultin, M.: Some take the glass escalator, some hit the glass ceiling?: Career consequences of occupational sex segregation. Work Occupation. 30(1), 30-61 (2003)

Jacobi, F., Hoyer, J., Wittchen, H.-U.: Seelische Gesundheit in Ost und West: Analysen auf der Grundlage des Bundesgesundheitssurveys. Z. Klin. Psychol. Psychother. 33(4), 251-260 (2004)

de Jonge, J., Bosma, H., Peter, R., Siegrist, J.: Job strain, effort-reward imbalance and employee well-being: a large-scale cross-sectional study. Soc. Sci. Med. 50(9), 1317-1327 (2000)

Kanter, R.M.: Men and women of the corporation. Basic Books, New York (1993)

Kato M., Yamazaki Y.: An examination of factors related to workto-family conflict among employed men and women in Japan. J. Occup. Health. 51(4):303-313 (2009)

Kessler, R.C.: Epidemiology of women and depression. J. Affect. Disord. 74(1), 5-13 (2003)

Kirchmeyer, C., Cohen, A.: Different strategies for man aging the work/non-work interface: a test for unique pathways to work outcomes. Work Stress. 13(1), 59-73 (1999)

Lau, B.: Effort-reward imbalance and overcommitment in employees in a Norwegian municipality: a cross-sectional study. J. Occup. Med. Toxicol. 3(9) (2008)

Leskinen, E., Cortina, L., Kabat, D.: Gender harassment: Broadening our understanding of sex-based harassment at work. Law Hum. Behav. 35(1), 25-39 (2011)

Li, J., Yang, W., Cho, S.-I.: Gender differences in job strain, effortreward imbalance, and health functioning among Chinese physicians. Soc. Sci. Med. 62(5), 1066-1077 (2006)

Major, V.S., Klein, K.J., Ehrhart, M.G.: Work time, work interference with family, and psychological distress. J. Appl. Psychol. 87(3), 427-426 (2002)

Mastekaasa, A.: Sickness absence in female- and male-dominated occupations and workplaces. Soc. Sci. Med. 60(10), 2261-2272 (2005)

Meyer, M., Weirauch, H., Weber, F.: Krankheitsbedingte Fehlzeiten in der deutschen Wirtschaft im Jahr 2011. In: Badura, B., Ducki, A., Schröder, H., Klose, J., Meyer, M. (eds.) Fehlzeiten-Report 2012. Gesundheit in der flexiblen Arbeitswelt: Chancen nutzen-Risiken minimieren, pp. 291-465. Springer, Berlin (2012)

Mota, N.P., Medved, M., Wang, J., Asmundson, G.J.G., Whitney, D., Sareen, J.: Stress and mental disorders in female military personell: Comparisons between the sexes in a male dominated profession. J. Psychiatr. Res. 46(2), 159-167 (2012)

Munce, S.E.P., Weller, I., Robertson Blackmore, E.K., Heinmaa, M., Katz, J., Stewart, D.E.: The role of work stress as a moderating variable in the chronic pain and depression association. J. Psychosom. Res. 61(5), 653-660 (2006)

Nolen-Hoeksema, S.: Gender differences in depression. Curr. Dir. Psychol. 10(5), 173-176 (2001)

Payne, S., Doyal, L.: Older women, work and health. Occup. Med. 60(3), 172-177 (2010)

Pejtersen, J.H., Kristensen, T.S., Borg, V., Bjorner, J.B.: The second version of the Copenhagen Psychosocial Questionnaire. Scand. J. Public Health. 38(3 suppl), 8-24 (2010)

Peter, R., Alfredsson, L., Hammar, N., Siegrist, J., Theorell, T., Westerholm, P.: High effort, low reward, and cardiovascular risk factors in employed Swedish men and women: baseline results from the WOLF Study. J. Epidemiol. Community Health. 52(9), 540-547 (1998)
Peter, R., Hammarström, A., Hallqvist, J., Siegrist, J., Theorell, T.: Does occupational gender segregation influence the association of effort-reward imbalance with myocardial infarction in the SHEEP study? Int. J. Behav. Med. 13(1), 34-43 (2006)

Pikhart, H., Bobak, M., Pajak, A., Malyutina, S., Kubinova, R., Topor, R., Sebakova, H., Nikitin, Y., Marmot, M.: Psychosocial factors at work and depression in three countries of Central and Eastern Europe. Soc. Sci. Med. 58(8), 1475-1482 (2004)

Rau, R., Gebele, N., Morling, K., Rösler, U.: Untersuchung arbeitsbedingter Ursachen für das Auftreten von depressiven Störungen. In: Bundesanstalt für Arbeitsschutz und Arbeitsmedizin (ed.). Dortmund (2010)

Schmitt, M., Altstötter-Gleich, C., Hinz, A., Maes, J., Brähler, E.: Normwerte für das Vereinfachte Beck-Depressions-Inventar (BDI-V) in der Allgemeinbevölkerung. Diagnostica. 52(2), 51-59 (2006)

Schröder, H., Kersting, A., Gilberg, R., Steinwede, J.: Methodenbericht zur Haupterhebung lidA-leben in der Arbeit. In: FDZ-Methodenreport 01/2013. Nürnberg (2013)

Schulz, M., Damkröger, A., Voltmer, E., Löwe, B., Driessen, M., Ward, M., Wingenfeld, K.: Work-related behaviour and experience pattern in nurses: impact on physical and mental health. J. Psychiatr. Ment. Health. 18(5), 411-417 (2011)

Shimazu, A., de Jonge, J.: Reciprocal relations between effort-reward imbalance at work and adverse health: A three-wave panel survey. Soc. Sci. Med. 68(1), 60-68 (2009)

Shuster, M.P.: The physical and psychological stresses of women in firefighting. Work. 15(1), 77-82 (2000)

Siegrist, J.: Adverse health effects of high-effort/low-reward conditions. J. Occup. Health Psychol. 1(1), 27-41 (1996)

Siegrist, J., Starke, D., Chandola, T., Godin, I., Marmot, M., Niedhammer, I., Peter, R.: The measurement of effort-reward imbalance at work: European comparisons. Soc. Sci. Med. 58(8), 1483-1499 (2004)

Simpson, R.: Masculinity at work: the experience of men in female dominated occupations. Work Employ. Soc. 18(2), 349-368 (2004)

Statistik der Bundesagentur für Arbeit: Arbeitsmarkt in Zahlen, Sozialversicherungspflichtig Beschäftigte nach Berufen (Klassifizierung der Berufe 1988). Nürnberg (2012)

Svedberg, P., Bildt, C., Lindelöw, M., Akexanderson, K.: Self-reported health among employees in relation to sex segregation at work sites. J. Occup. Health. 51(3), 223-231 (2009)

Techniker Krankenkasse: TK Gesundheitsreport Auswertungen 2008. Arbeitsunfähigkeiten und Arzneiverordnungen. Schwerpunkt psychische Störungen. Hamburg (2008)

Tennant, C.: Work-related stress and depressive disorders. J. Psychosom. Res. 51(5), 697-704 (2001)

Tsutsumi, A., Kawanami, S., Horie, S.: Effort-reward imbalance and depression among private practice physicians. Int. Arch. Occup. Environ. Health. 85(2), 153-161 (2012)

van Veldhoven, M.J.P.M., Beijer, S.E.: Workload, work-to-family conflict, and health: Gender differences and the influence of private life context. J. Soc. Issues. 68(4), 665-683 (2012)

Vogel, C.: Teilzeitbeschäftigung-Ausmaß und Bestimmungsgründe der Erwerbsübergänge von Frauen. Z. ArbeitsmarktForschung. 42(2), 170-181 (2009)

Wang J, Patten SB, Currie S, Sareen J, Schmitz N A population-based longitudinal study on work environmental factors and the risk of major depressive disorder. Am. J. Epidemiol. 176(1), 52-59 (2012)

Whitley, T.W., Allison, E.J.J., Gallery, M.E., Heyworth, J., Cockington, R.A., Gaudry, P., Revicki, D.A.: Work-related stress and depression among physicians pursuing postgraduate training in emergency medicine: An international study. Ann. Emerg. Med. 20(9), 992-996 (1991) 
Silke Tophoven is a sociologist and researcher in the project "lidAleben in der Arbeit. German Cohort Study on Work, Age and Health" at the Institute for Employment Research (IAB) in Nuremberg, Germany. Her main research interests include labour force participation over the life-course, the relationship between work and health, and gender inequalities.

Jean-Baptist du Prel MD, MPH is an epidemiologist and researcher in the project "lidA-leben in der Arbeit. German Cohort Study on Work, Age and Health" at the Institute of the History, Philosophy and Ethics of Medicine at Ulm University, Germany. His research interests include social status, gender research, work stress, work-family-conflict, coping, aging at work, occupational health and epidemiological methods.
Richard Peter is a medical sociologist with a background in social sciences. He is a professor at the Institute of the History, Philosophy and Ethics of Medicine at Ulm University, Germany. His main research interests relate to health inequalities and to psychosocial factors at the worksite and their association with health.

Veronika Kretschmer is a researcher in the study "lidA-leben in der Arbeit. German Cohort Study on Work, Age and Health" at the Bergische University of Wuppertal, Germany. Her main research interests are healthy aging at work, early retirement, atypical employment and gender. She received her $\mathrm{PhD}$ in psychology from the Technical University of Dortmund in April 2014. 